\title{
A benthic sled for sampling soft bottoms
}

\author{
S. Blomqvist \& L. Lundgren \\ Department of Systems Ecology, Section Marine Ecology, Stockholm University; \\ S-106 91 Stockholm, Sweden
}

\begin{abstract}
A new benthic sled is described. Favourable features of the sled include: simple operation, broad runners, balanced towing position, simple height adjustment of the sediment cutting edge and quick exchange of the collecting bag. Metallic parts are aluminium, making the sled light $(15 \mathrm{~kg})$. This sled has functioned well in coastal research for more than a decade.
\end{abstract}

\section{INTRODUCTION}

The benthic sled is a basic piece of gear that is drawn across the sediment surface to collect bottom organisms (see reviews by Menzies, 1964; Menzies et al., 1973; Eleftheriou \& Holme, 1984; McIntyre \& Warwick, 1984; Schwoerbel, 1986; and bibliographies by McIntyre, 1970; Rosenberg, 1978; Elliott et al., 1993), and sometimes also to collect nodules (Kidd et al., 1990). In essence, a sled is a demersal trawl provided with runners. Usually, benthic sleds are slowly towed by a boat, but there are also designs for operation by wading in the intertidal zone (Pullen et al., 1968), and for diver operation in deeper water (Sibert et al., 1977). On soft bottoms, sleds are often preferred to traditional dredges because they can, if properly designed and handled, skim off the surface of a considerable stretch of bottom, without digging too deep into the sediment and clogging with mud.

A commonly used type of benthic sled is that described by Ockelmann (1964), primarily designed for collecting meiobenthos and small macrofauna in coastal waters. Hessler \& Sanders (1967) describe another sled intended for sampling invertebrate macrofauna of the deep-sea floor. In the present paper we report on a similar type of benthic sled, inspired by these two gears, but with several useful modifications.

\section{DESCRIPTION AND OPERATION}

The benthic sled is double-sided (Fig. 1), light-weight ( $15 \mathrm{~kg}$ ), and can be operated from a small craft. The double-sided design allows the sled to operate properly no matter what side is up when it settles on the bottom. The sled has two broad runners to prevent it from sinking too deeply into the sediment. The runners are joined by stout front and rear cross members, and by two cutting blade bars. The leading tapered edge of the blades point forward. These bars, and two uprights, form a frame for the attachment of the rectangular, canvas-lined opening of the collecting bag. The bag is secured to the cut- 


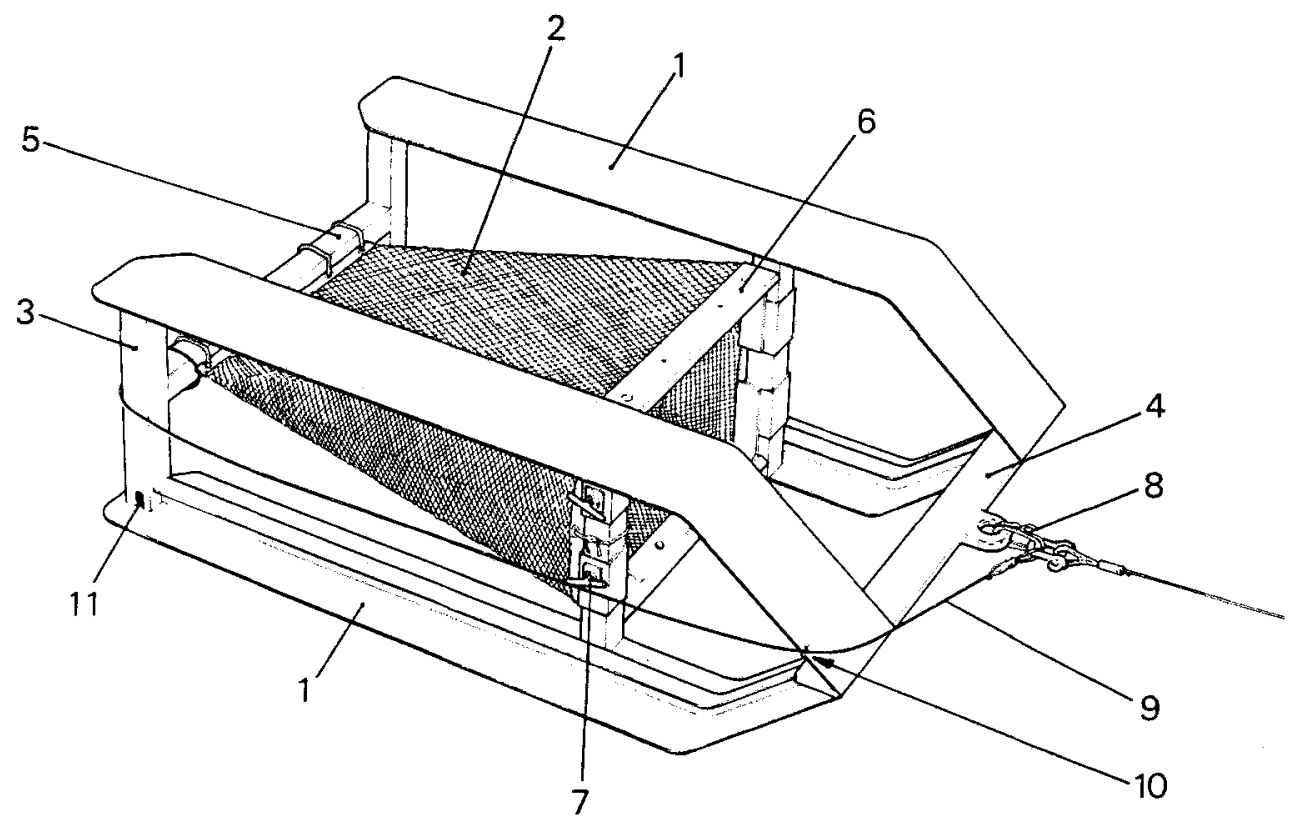

Fig. 1. Drawing of the benthic sled. Dimensions of the sled: total length $1125 \mathrm{~mm}$, total breadth $700 \mathrm{~mm}$, cutting breadth $400 \mathrm{~mm}$ and bag volume 55 litres. 1: runners; 2 : collecting bag; $3:$ upright (hollow); 4: front cross member (solid); 5 : rear cross member (hollow); 6 : cutting blade bar; 7 : wing-bolts of linear guide; 8: weak link (polyester cable); 9: safety wire; 10: safety wire holder; 11: drainage hole

ting blades with screw mounted aluminium strips. The cutting blade is designed to cut off a layer of surface sediment, which then passes back into the bag. The back end of the bag is tied to the rear cross member. Throughout, the metallic parts are aluminium alloys (DIN 1725: AlMg 2.5 and AIMgSi 0.5). In addition to being light weight, these alloys are resistant to corrosion and are easy to keep clean.

The blade bars can be moved vertically, by loosening the wing-bolts of the linear guides, allowing easy adjustment of the cutting depth. The blades can be set from $40 \mathrm{~mm}$ beneath the runners to $35 \mathrm{~mm}$ above the runners. The collecting bag consists of an outer bag of strong twine netting (mesh size $10 \mathrm{~mm}$ ), usually used in combination with an inner fine lining of variable mesh size (usually 1 or $0.5 \mathrm{~mm}$ ). The bag is easy to exchange, by untying the fixing strings, which are interlinked by brass grommets, and unscrewing the covering strips. The bags are shaped like a triangle in long section in order to facilitate sediment winnowing and the collection of organisms.

The leading edge of the collecting bag is set at a position on the runners which maintains the sled in a level position during towing, even when the bag is loaded with sediment (Fig. 2). No ballast is needed. A minimum length of towing wire of four times the water depth is recommended. The towing wire is connected to the front cross member, via a weak-link (polyester cable). This link arrangement (Fig. 1) helps prevent the tow wire from breaking, should the sled become fouled on the bottom. When the weak-link 


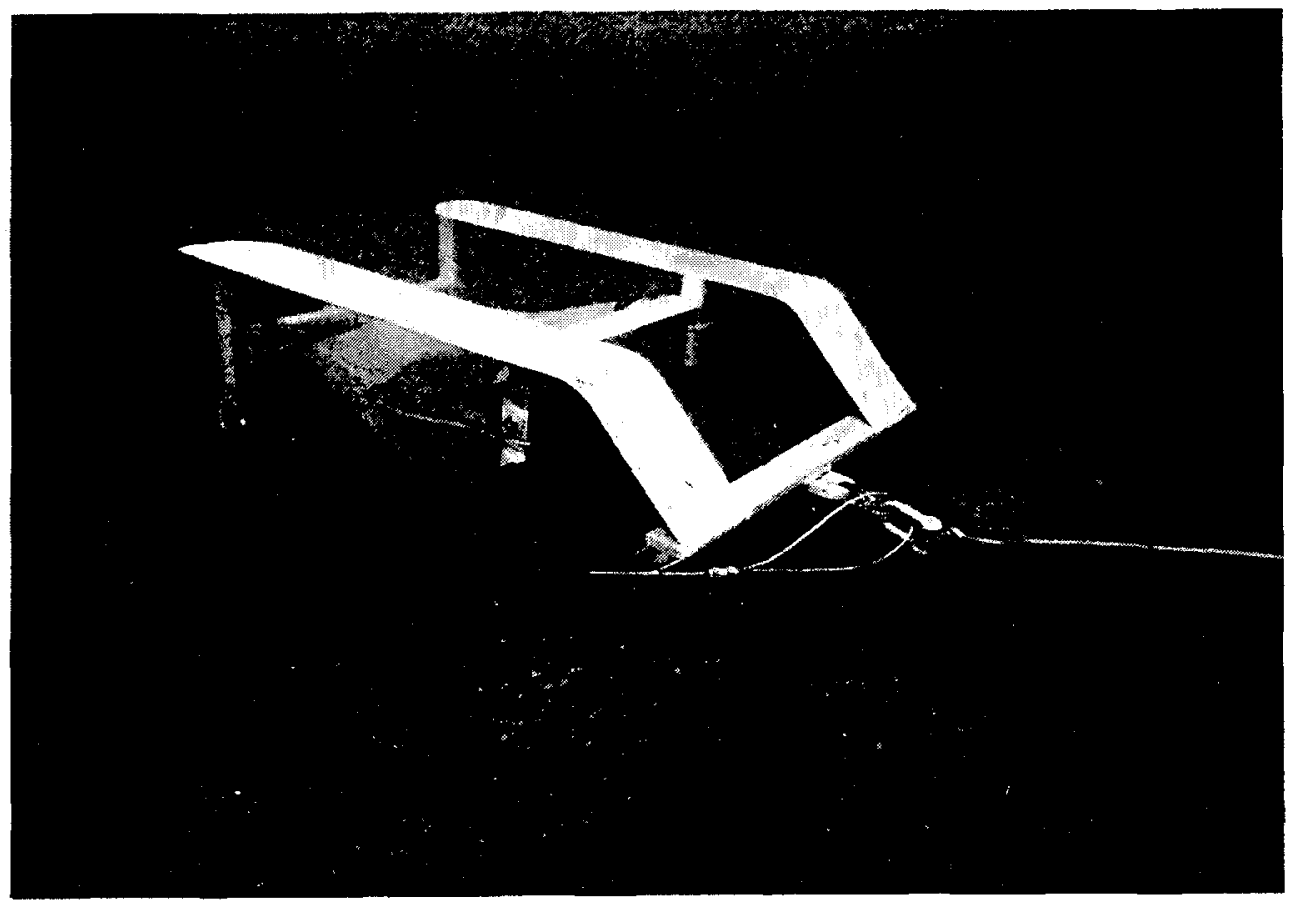

Fig. 2. Underwater photograph of the benthic sled, operating on a soft sediment at a depth of $10 \mathrm{~m}$ in the Baltic Sea

snaps, load is transferred to the safety wire attached to the rear cross member, and the sled jolts sideways, thus normally freeing itself.

\section{CONCLUDING REMARKS}

Compared to similar benthic sleds, the present device has the following advantages: (1) a convenient design which is simple to operate, (2) a balanced towing position with little tendency to upset during sampling (cf. Menzies 1972; Menzies et al., 1973), (3) easy adjustment of cutting bar height, and (4) quick exchange of collecting bags. The sled has functioned well during collections of benthic animals in coastal areas of the Baltic Sea for more than a decade (Lopez \& Elmgren, 1989; Abrams et al., 1990; Hill et al., 1990, 1992; Ólafsson \& Elmgren, 1991; Ólafsson, 1992; Ólafsson et al., 1993; Eriksson et al., 1996). A larger model (cutting breadth $800 \mathrm{~mm}$ ) has been used successfully for shipboard sampling of epibenthic mysids (Rudstam et al., 1989), and for sampling demersal fish in shallow water by manual hauling ashore (Nellbring, 1988).

Acknowledgements. We thank R. Elmgren, D. Duplisea and J. D. Gage for comments and linguistic improvements of the manuscript. LL was responsible for the technical development and construction of the sled, and SB received support from the Swedish Environmental Protection Agency (Naturvårdsverket) and the Swedish Natural Science Research Council (NFR) for publishing. 


\section{LITERATURE CITED}

Abrams, P. A., Hill, C. \& Elmgren, R., 1990. The functional response of the predatory polychaete, Harmothoe sarsi, to the amphipod, Pontoporeia affinis. - Oikos 59, 261-269.

Eleftheriou, A. \& Holme, N. A., 1984. Macrofauna techniques. In: Methods for the study of marine benthos. Ed: by N. A. Holme \& A. D. McIntyre. Blackwell, Oxford, 140-216.

Elliott, J. M., Tullett, P. A. \& Elliott, J. A., 1993. A new bibliography of samplers for freshwater benthic invertebrates. - Occ. Publ. Freshwat. Biol. Ass. 30,1-92.

Eriksson, A.-K., Sundelin, B., Broman, D. \& Näf, C., 1996. Reproduction effects on Monoporeia affinis of HPLC-fractionated extracts of sediments from a pulp mill recipient. In: Environmental fate and effects of pulp and paper mill effluents. Ed. by M. R. Servos, K. R. Munkittrick, J. H. Carey \& G. J. Van Der Kraak. St. Lucie Press, Delray Beach, Florida, 69-78.

Hessler, R. R. \& Sanders, H. L., 1967. Faunal diversity in the deep-sea. - Deep-Sea Res. 14, 65-78.

Hill, C., Elmgren, R. \& Abrams, P., 1990. Predation by the polychaete Harmothoe sarsi on different size classes of the amphipod Pontoporiea affinis. In: Trophic relationships in the marine environment. Ed. by M. Barnes \& R. N. Gibson. Aberdeen University Press, Aberdeen, 468-477.

Hill, C., Quigley, M. A., Cavaletto, J. F. \& Gordon, W., 1992. Seasonal changes in lipid content and composition in the benthic amphipods Monoporeia affinis and Pontoporeia femorata. - Limnol. Oceanogr. 37, 1280-1289.

Kidd, R. B., Huggett, Q. J. \& Ramsay, A. T. S., 1990. The status of geological dredging techniques. Mar. geophys. Res. 12, 131-143.

Lopez, G. \& Elmgren, R., 1989. Feeding depths and organic absorption for the deposit-feeding benthic amphipods Pontoporeia affinis and Pontoporeia femorata. - Limnol. Oceanogr. 34, 982-991.

McIntyre, A. D. (ed.), 1970. Bibliography on methods of studying the marine benthos. - F. A. O. Fish. tech. Pap. 98, 1-96.

McIntyre, A. D. \& Warwick, R. M., 1984. Meiofauna techniques. In: Methods for the study of marine benthos. Ed. by N. A. Holme \& A. D. Mclntyre. Blackwell, Oxford, 217-244.

Menzies, R. J., 1964. Improved techniques for benthic trawling at depths greater than 2000 meters. Antarct. Res. Ser. 1, 93-109.

Menzies, R. J., 1972. Current deep benthic sampling techniques from surface vessels. In: Barobiology and the experimental biology of the deep sea. Ed. by R. W. Brauer. Univ. North Carolina, Chapel Hill, 164-169.

Menzies, R. J., George, R. Y. \& Rowe, G. T., 1973. Abyssal environment and ecology of the world oceans. Wiley, New York, 488 pp.

Nellbring, S., 1988. Food choice of small fish in shallow water, northern Baltic proper. Competition and impact on macrofauna? In: Quantitative and qualitative studies of fish in shallow water, northern Baltic proper. Ph.D. Thesis, Univ. Stockholm, 83-98.

Ockelmann, K. W., 1964. An improved detritus-sledge for collecting meiobenthos. - Ophelia 1 , $217-222$

Ólafsson, E., 1992. Small-scale spatial distribution of marine meiobenthos: the effects of decaying macrofauna. - Oecologia 90, 37-42.

Ólafsson, E. \& Elmgren, R., 1991. Effects of biological disturbance by benthic amphipods Monoporeia affinis on meiobenthic community structure: a laboratory approach. - Mar. Ecol. Prog. Ser. 74, 99-107.

Olafsson, E., Elmgren, R. \& Papakosta, O., 1993. Effects of the deposit-feeding benthic bivalve Macoma balthica on meiobenthos. - Oecologia 93, 457-462.

Pullen, E. J., Mock, C. R. \& Ringo, R. D., 1968. A net for sampling the intertidal zone of an estuary. Limnol. Oceanogr. 13, 200-202.

Rosenberg, D. M., 1978. Practical sampling of freshwater macrozoobenthos: a bibliography of useful texts, reviews, and recent papers. - Tech. Rep. Fish. mar. Serv. 790, 1-15.

Rudstam, L. G., Danielsson, K., Hansson, S. \& Johansson, S., 1989. Diel vertical migration and feeding patterns of Mysis mixta (Crustacea, Mysidacea) in the Baltic Sea. - Mar. Biol. 101, 43-52.

Schwoerbel, J., 1986. Methoden der Hydrobiologie. Fischer, Stuttgart, 301 pp.

Sibert, J., Kask, B. A. \& Brown, T. J., 1977. A diver-operated sled for sampling the epibenthos. - Tech. Rep. Fish. mar. Serv. 738, 1-19. 